\title{
Analisis Faktor Risiko Kejadian Infeksi Saluran Pernapasan Akut ditinjau dari Lingkungan Fisik
}

\section{Risk Factors Analysis of Acute Respiratory Infections Reviewed from The Physicalenvironment}

\author{
Suci Wulandhani ${ }^{1)^{*}}$, A. Bida Purnamasari ${ }^{1)}$ \\ ${ }^{1}$ Biologi, STKIP Pembangunan Indonesia, Makassar Indonesia \\ Received $24^{\text {th }}$ August $2019 /$ Accepted $24^{\text {th }}$ September 2019
}

\begin{abstract}
ABSTRAK
Infeksi Saluran Pernapasan Akut merupakan penyebab utama morbiditas dan mortalitas penyakit menular dunia. Penyakit-penyakit berbasis lingkungan memang masih merupakan penyebab utama kematian di Indonesia. Penyakit ISPA di Indonesia berada pada 10 daftar penyakit terbanyak di rumah sakit. Berdasarkan laporan Dinkes Kota Makassar yang bersumber dari bidang Pengendalian Penyakit dan Penyehatan Lingkungan, penyakit ISPA menjadi penyakit utama nomor 1 di Kota Makassar diantara 9 penyakit lainnya dengan jumlah kasus ISPA tahun 2015 sebanyak 45.569 dan pada tahun 2016 sebanyak 44.819 kasus. Salah satu faktor yang dapat menyebabkan tingginya angka kejadian ISPA adalah faktor lingkungan fisik. Penelitian ini bertujuan untuk mengetahui seberapa besar faktor risiko kualitas lingkungan fisik terhadap kejadian ISPA. Penelitian ini menggunakan teknik simple random sampling dengan sample berjumlah 59 orang yang selanjutnya diolah dengan uji crosstab. Hasil penelitian menunjukkan bahwa ada hubungan yang bermakna antara kepadatan hunian $(O R=2.030, R R=0.635,95 \% C I: 0.673-6.128)$, ventilasi $(O R=0.814, R R=1.138,95 \%$ $C I$ : 0.280-2.369), jenis lantai $(O R=0.768, R R=1.173,95 \% C I: 0.155-3.802)$, jenis dinding $(O R=5.294, R R=0.324,95 \% C I: 1.499-18.695)$ jarak antara rumah dengan jalan raya $(O R=1.167, R R=0.909,95 \% C I: 0.351-3.881)$ dan kebiasaan membersihkan debu dalam rumah $(O R=1.228, R R=0.879,95 \% C I: 0.422-3.572)$ dengan kejadian ISPA.
\end{abstract}

Kata Kunci : ISPA, Faktor Risiko, Lingkungan Fisik

\begin{abstract}
Acute respiratory infections are a major cause of morbidity and mortality in infections diseases of the world. Environment based diseases are still the main cause of death in Indonesia. ISPA in Indonesia is on the top 10 list of diseases in hospitals. Based on the Makassar city health office report, ISPA became the number one disease in Makassar city among 9 other diseases with 45.569 cases in 2015 and 44.819 ISPA cases in 2016. One of the factor that can cause a high incidence of ISPA is the physical environment. This study aims to determine how much the risk factor for the quality of the physical environment agaits ISPA events. This study uses simple random sampling technique with a sample 59 people which are then processed by crosstab test. The result showed that there was a relationship of residentialdensity $(O R=2.030, R R=0.635)$,
\end{abstract}

*Korespondensi:

email: suci.byomosq@gmail.com 
ventilation $(O R=0.814, R R=1.138)$, type of floor $(O R=0.768, R R=1.173)$, type of wall $(O R=5.294, R R=0.324)$, distance between the house and the highway $(O R=$ 1.167, $R R=0.909)$ and cleaning habits $(O R=1.228, R R=0.879)$ with ISPA events.

Keywords : ISPA, Risk Factors, Physical Environment

\section{PENDAHULUAN}

Infeksi Saluran Pernapasan Akut (ISPA) merupakan penyebab utama morbiditas dan mortalitas penyakit menular dunia. Hampir empat juta orang meninggal akibat ISPA setiap tahun (WHO, 2012). ISPA merupakan salah satu masalah kesehatan yang ada di negara berkembang dan negara maju. Hal ini disebabkan karena masih tingginya angka kesakitan dan angka kematian karena ISPA terutama pada bayi dan balita.

Penyakit-penyakit berbasis lingkungan memang masih merupakan penyebab utama kematian di Indonesia. Pada tahun 2001, kematian yang disebabkan oleh penyakit berbasis lingkungan, diantaranya ISPA menduduki peringkat pertama dengan jumlah $15,7 \%$ kematian, penyakit TBC menduduki peringkat kedua dengan jumlah 9,6\% kematian. Diare menduduki peringkat ketiga dengan jumlah $7,4 \%$ kematian. Secara total penyakit berbasis lingkungan menyumbangkan 33\% atau sepertiga total kematian seluruh kelompok umur. Sedangkan pada kelompok balita, pola penyebab kematian ini lebih tinggi lagi yaitu 30,8\% kematian dan menduduki urutan pertama pola penyakit pada balita sebanyak 19,4 per 1000 balita.

Laporan Dinas Kesehatan Kota Makassar yang bersumber dari bidang Pengendalian Penyakit dan Penyehatan Lingkungan (P2PL), menunjukkan bahwa penyakit ISPA menjadi penyakit utama nomor 1 di Kota Makassar diantara 9 penyakit lainnya dengan jumlah kasus ISPA tahun 2013 sebanyak 53.730, tahun 2014 sebanyak 49.118, tahun 2015 sebanyak 45.569 dan pada tahun 2016 sebanyak 44.819 kasus. Berdasarkan data rekam medik di Puskesmas Malimongan Baru Kecamatan Bontoala Kota Makassar bahwa jumlah penderita ISPA pada balita sebanyak 56 lebih banyak dibanding data puskesmas kecamatan lainnya di Kota Makassar. Hal ini mendasari peneliti untuk melihat faktor risiko dan relative riskdari kejadian ISPA ditinjau dari lingkungan fisik di Kecamatan Bontoala Kota Makassar.

\section{METODE}

\section{Lokasi dan Rancangan penelitian}

Penelitian ini dilaksanakan di Kecamatan Kecamatan Bontoala Makassar yang meliputi 12 Kelurahan yaitu Kelurahan Timungan Lompoa, Kelurahan Tompo Balang, Kelurahan Wajo Baru, Kelurahan Malimongan Baru,Kelurahan Baraya, Kelurahan Bungaejaya, Kelurahan Layang, Kelurahan Parang Layang, Kelurahan Bontoala, Kelurahan Bontoala Tua, Kelurahan Bontoala Parang, dan Kelurahan Gaddong. Metode analisis data yang digunakan adalah dengan menduga parameter dari data mengenai penyakit ISPA di Kecamatan Bontoala tahun 2016 sampai dengan April 2019 yang diperoleh di Dinas Kesehatan Kota Makassar dan Puskesmas di Kecamatan Bontoala Makassar. Kegunaan metode ini adalah untuk mendapatkan informasi awal parameter dari area kecil yang telah ditentukan yakni 12 Kelurahan di Kecamatan Bontoala. Untuk 
data primer menggunakan teknik simple random sampling dengan besar sample berjumlah 59 orang yang selanjutnya diolah dengan uji statistik cross tab dengan tingkat kepercayaan 95\%, a $=5 \%$ untuk mengetahui faktor risiko dan relative risk lingkungan fisik terhadap kejadian ISPA.

\section{Populasi dan sampel}

Populasi dalam penelitian ini diambil dari Dinas Kesehatan Kota Makassar yakni warga Kecamatan Bontoala yang tercatat memiliki kasus kejadian ISPA. Pemilihan sampel yang dilakukan dalam penelitian ini adalah penderita ISPA yang ditemukan di tiap puskesmas di Kecamatan Bontoala Makassar.

\section{Pengumpulan Data}

Data primer yang dikumpulkan berupa hasil observasi dan wawancara langsung yang dilakukan di tiap kelurahan, sedangkan data sekunder berupa data penderita ISPA yang mendapatkan pelayanan di masing-masing puskesmas di Kecamatan Bontoala.

\section{Analisis data}

Untuk melihat risiko dan peluang masyarakat sekitar untuk terkena penyakit ISPA yang ditemukan di tiap Kelurahan maka dilakukan analisis data secara kualitatif menggunakan program Microsoft Exel dan Program iBM statistik (SPSS) untuk mendeskripsikan hasil pengolahan datadan untuk mengetahui faktor risiko dan relative riskvariabel lingkungan fisik rumah dengan variabel kejadian ISPA.

\section{HASIL DAN PEMBAHASAN}

Lingkungan fisik rumah merupakan salah satu faktor yang berhubungan dengan kejadian ISPA. Rumah permanen pada umumnya memiliki lantai, dinding, tingkat kepadatan sedangkan rumah dengan tipe semi permanen dan tidak permanen kebanyakan kondisi fisiknya masih kurang memenuhi syarat kesehatan.

Hasil analisis hubungan faktor lingkungan fisik dengan kejadian ISPA di Kecamatan Bontoala dengan uji statistik crosstab dapat dilihat pada tabel dibawah ini.

Tabel 1. Hubungan Lingkungan Fisik dengan Kejadian ISPA

\begin{tabular}{|c|c|c|c|c|c|}
\hline \multirow{2}{*}{ Variabel } & \multicolumn{2}{|c|}{ ISPA } & \multirow{2}{*}{$\mathbf{O R}$} & \multirow{2}{*}{$\mathbf{R R}$} & \multirow[b]{2}{*}{$95 \% \mathrm{CI}$} \\
\hline & Ya & Tidak & & & \\
\hline \multicolumn{6}{|l|}{ Kepadatan Hunian } \\
\hline Tidak memenuhi syarat & 18 & 7 & \multirow{2}{*}{2,030} & \multirow{2}{*}{0,635} & $0,673-6,128$ \\
\hline Memenuhi syarat & 19 & 15 & & & \\
\hline \multicolumn{6}{|l|}{ Ventilasi } \\
\hline Tidak memenuhi syarat & 20 & 13 & \multirow{2}{*}{0,814} & \multirow{2}{*}{1,138} & $0,280-2,369$ \\
\hline Memenuhi syarat & 17 & 9 & & & \\
\hline \multicolumn{6}{|l|}{ Jenis lantai } \\
\hline Tidak memenuhi syarat & 4 & 3 & \multirow{2}{*}{0,768} & \multirow{2}{*}{1,173} & $0,155-3,802$ \\
\hline Memenuhi syarat & 33 & 19 & & & \\
\hline
\end{tabular}




\begin{tabular}{|c|c|c|c|c|c|}
\hline \multirow{2}{*}{ Variabel } & \multicolumn{2}{|c|}{ ISPA } & \multirow{2}{*}{$\mathbf{O R}$} & \multirow{2}{*}{$\mathbf{R R}$} & \multirow{2}{*}{$95 \% \mathrm{CI}$} \\
\hline & Ya & Tidak & & & \\
\hline \multicolumn{6}{|l|}{ Dinding Rumah } \\
\hline Tidak memenuhi syarat & 20 & 4 & \multirow{2}{*}{5,294} & \multirow{2}{*}{0,324} & \multirow[t]{2}{*}{$1,499-18,695$} \\
\hline Memenuhi syarat & 17 & 18 & & & \\
\hline \multicolumn{6}{|l|}{ Jarak Rumah } \\
\hline Tidak memenuhi syarat & 28 & 16 & \multirow{2}{*}{1,167} & \multirow{2}{*}{0,909} & \multirow[t]{2}{*}{$0,351-3,881$} \\
\hline Memenuhi syarat & 9 & 6 & & & \\
\hline \multicolumn{6}{|c|}{ Kebiasaan Membersihkan } \\
\hline Tidak memenuhi syarat & 17 & 9 & \multirow{2}{*}{1,228} & \multirow{2}{*}{0,879} & \multirow[t]{2}{*}{$0,422-3,572$} \\
\hline Memenuhi syarat & 20 & 13 & & & \\
\hline
\end{tabular}

Berdasarkan tabel 1 diketahui bahwa sebagian besar responden memiliki kepadatan hunian yang tidak memenuhi syarat yaitu sebanyak 18 responden $(48,65 \%)$ dari total 59 responden. Ventilasi rumah yang tidak memenuhi syarat yaitu sebanyak 20 responden $(54,05 \%)$. Untuk jenis lantai dan jenis dinding yang tidak memenuhi syarat masingmasing sebanyak 4 responden $(10,81 \%)$ dan 20 responden $(54,05 \%)$. Sedangkan jarak rumah dengan jalan raya yang tidak memenuhi syarat sebanyak 28 responden (75,68\%)dan kebiasaan membersihkan rumah yang tidak memenuhi syarat sebanyak 17 responden (45,95\%). Kejadian ISPA di Kecamatan Bontoala diketahui bahwa sebagian besar responden menderita ISPA yaitu sebanyak 37 responden dari total 59 responden.

Hasil analisis dengan menggunakan odds rasio (OR) bermakna secara statistik (95\% confidence internal) diperoleh nilai $\mathrm{OR}=2,030$ (nilai $\mathrm{OR}>1$ ) artinya rumah dengan penghuni yang padat mempunyai risiko 2,030 kali untuk menderita ISPA dibanding dengan rumah dengan penghuni yang tidak padat. Hal ini menunjukkan bahwa kepadatan hunian merupakan faktor risiko kejadian ISPA. Penelitian ini sejalan dengan penelitian yang dilakukan oleh Asriati dkk (2013) yang menunjukkan bahwa ada hubungan antara kepadatan hunian rumah dengan kejadian ISPA pada anak balita di Kota Kendari. Hasil analisis hubungan antara kepadatan hunian rumah dengan kejadian ISPA pada anak balita menunjukkan bahwa dari 68 responden diperoleh nilai OR hitung 3,569 artinya balita yang tinggal dirumah dengan penghuni padat mempunyai risiko 3,569 untuk menderita ISPA dibanding dengan balita yang tinggal dirumah dengan penghuni tidak padat. Penelitian ini juga sejalan dengan penelitian Cahya (2011) dimana uji chi square menunjukkan $\mathrm{p}=0,000$ dan nilai OR sebesar 8,254, secara statisik ada hubungan bermakna antara kepadatan hunian dengan kejadian ISPA. Jumlah orang yang tinggal dalam satu rumah dapat mempengaruhi penyebaran penyakit menular dalam kecepatan transmisi mikroorganisme.

Hasil analisis untuk masing-masing faktor lingkungan seperti ventilasi dan jenis lantai memiliki nilai $\mathrm{OR}=0,814$ dan0,768artinya responden yang memiliki ventilasi rumah yang kurang baik memiliki risiko akan mengalami ISPA 0,814 kali lebih besar dibandingkan dengan rumah yang mempunyai ventilasi yang baik dan responden yang 
memiliki jenis lantai yang kurang baik memiliki risiko akan mengalami ISPA 0,768 kali lebih besar dibandingkan dengan rumah yang memiliki jenis lantai yang baik. Hasil ini menunjukkan bahwa sebagian rumah responden memiliki ventilasi yang kurang baik. Berdasarkan kepmenkes RI No. 829/Menkes/SK/VII/1999, syarat ventilasi rumah sehat yaitu $\geq 10 \%$ dari luas lantai.Hasil ini sejalan dengan penelitian yang dilakukan oleh Safrizal (2017) yang menujukkan bahwa ada hubungan yang bermakna antara ventilasi rumah dengan kejadian ISPA pada balita di Gampong Blang Muko dimana didapatkan nilai $p$ value $0,032<0,05$ dan nilai $\mathrm{OR}$ yaitu 2,590 yang artinya bahwa seseorang yang mempunyai ventilasi rumah kurang baik memiliki risiko akan mengalami ISPA 2,590 kali lebih besar di bandingkan dengan seseorang yang mempunyai ventilasi rumah dengan baik.

Hasil uji statistik diperoleh kondisidinding rumahmempunyai hubungan yang bermakna dengan kejadian ISPA. Besarnya risiko untuk terkena ISPA dapat dilihat dengan nilai $\mathrm{OR}=5,294$ yang artinya rumah dengan jenis dinding yang tidak memenuhi syarat memiliki risiko terkena ISPA sebesar 5,294 kali lebih besar dibandingkan dengan rumah yang kondisi dindingnya memenuhi syarat. Hasil penelitian ini sejalan dengan penelitian yang dilakukan oleh Aji (2008) di Kabupaten Cilacap yang menunjukkan bahwa kondisi dinding rumah yang dibuat secara tidak permanen berhubungan dengan terjadinya ISPA dimana nilai $p=0,017$ dan $\mathrm{OR}=3,59$. Sehingga dapat disimpulkan jenis dinding rumah yang dibuat secara tidak permanen dapat mempengaruhi kelembaban di dalam rumah dan kelembaban dapat mempengaruhui berkembangnya penyebab ISPA.

Jarak rumah yang berdekatan dengan jalan raya memiliki nilai OR sebesar 1,167. Hal ini berarti bahwa rumah yang dekat dengan jalan raya mempunyai kemungkinan 1,167 kali lebih besar untuk mengalami ISPA dibandingkan dengan rumah yang jauh dengan jalan raya. Hasil penelitian ini sejalan dengan penelitian yang dilakukan oleh Setyaningsih (2016), berdasarkan hasil analisisn dengan uji chi square diperoleh nilai $p$ sebesar 0,014 yang menunjukkan bahwa secara statistik terdapat hubungan yang bermakna antara jarak tempat tinggal dengan jalan raya dengan kejadian ISPA pada anak di Kecamatan Sragen. Sedangkan parameter kekuatan hubungan didapatkan nilai $\mathrm{OR}=3,09$ dengan CI 95\% antara 1,24-7,70. Hal ini berarti bahwa anak yang rumahnya dekat dengan jalan raya mempunyai kemungkinan 3,09 kali lebih besar untuk mengalami ISPA dibanding dengan anak yang tempat tinggalnya jauh dengan jalan raya.

Kebiasaan membersihkan rumah mempunyai hubungan yang bermakna dengan kejadian ISPA. Besarnya risiko untuk terkena ISPA dapat dilihat dengan nilai OR = 1,228yang artinya rumah yang jarang dibersihkan memiliki risiko terkena ISPA sebesar 1,228 kali lebih besar dibandingkan dengan rumah yang sering dibersihkan. Sebagian responden sudah memiliki kebiasaan membersihkan rumah dari debu dengan melap perabotan rumah, menyapu dan mengepel, tetapi hal ini masih saja membuat debu dapat masuk ke dalam rumah dikarenakan kendaraan yang melintas disekitar rumah.

Dari hasil analisis data dilakukan uji statistik status lingkungan fisik terhadap kejadian ISPA dengan uji crosstab. Hasil menunjukkan bahwa dari ke enam faktor 
lingkungan fisik, jenis dinding memiliki odds ratio tertinggi. Responden yang memiliki dinding rumah tidak memenuhi syarat (TMS) lebih besar dibandingkan dengan responden yang memiliki dinding rumah yang memenuhi syarat (MS) terhadap penyakit ISPA. Ini diketahui dari “odds ratio for Dinding Rumah (TMS/MS)” dimana responden yang memiliki dinding rumah TMS sebagai pembilang (numerator) dan responden yang memiliki dinding rumah MS sebagai penyebut (denominator). Nilai Odds ratio sebesar 5.294 berarti responden yang memiliki dinding rumah TMS memiliki kecenderungan untuk menderita ISPA sebesar 5,294 atau 5 kali lebih besar dibandingkan dengan responden yang memiliki dinding rumah MS. Berdasarkan uji statistik diperoleh selang kepercayaan $(1,499-18,695)$ dimana pada selang kepercayaan tidak mengandung nilai odds ratio 1 sehingga menunjukan adanya hubungan antara jenis dinding rumah dengan menderita ISPA pada taraf signifikansi $5 \%$

Relative risk dihitung dengan membandingkan responden yang memiliki dinding rumah tidak memenuhi syarat (TMS) dengan responden yang memiliki dinding rumah memenuhi syarat (MS). Relative risk untuk tidak menderita ISPA dihitung dengan membandingkan peluang responden yang memiliki dinding rumah TMS dengan responden yang memiliki dinding rumah MS. Relative risknya di SPSS dapat dilihat pada "For cohort ISPA = Tidak ISPA", Yaitu 1,716. Artinya responden yang memiliki dinding rumah MS memiliki peluang untuk Tidak ISPA 1,716 atau 2 kali lebih besar dibandingkan dengan responden yang memiliki dinding rumah TMS. Relative risk untuk menderita ISPA dihitung dengan membandingkan peluang responden yang memiliki dinding rumah TMS dengan responden yang memiliki dinding rumah MS. Relative risknya di SPSS dapat dilihat pada "For cohort ISPA = Menderita ISPA", yaitu 0,324, artinya responden yang memiliki dinding rumah MS memiliki peluang atau resiko untuk menderita ISPA 0,324 kali lebih kecil dibandingkan dengan responden yang memiliki dinding rumah TMS.

Penyakit ISPA adalah penyakit yang timbul karena menurunnya sistem kekebalan atau daya tahan tubuh, misalnya karena kelelahan atau stres. Bakteri dan virus penyebab ISPA di udara bebas akan masuk dan menempel pada saluran pernapasan bagian atas, yaitu tenggorokan dan hidung.Berdasarkan hasil penelitian yang dilakukan di Kecamatan Bontoala diketahui bahwa sebagian besar responden menderita ISPA yang bersifat ringan seperti batuk pilek. Pekerjaan akan sangat mempengaruhi penghasilan yang rendah membuat seseorang tidak dapat memilih bahan bangunan yang tidak berkualitas. Hal ini dapat terjadi karena perilaku hidup masyarakat yang belum mengacuh pada perilaku hidup sehat misalnya menciptakan rumah yang bersih dan sehat sesuai dengan standar kesehatan menurut Departemen Kesehatan RI. Oleh karena itu masyarakat perlu mengetahui kriteria rumah yang baik bagi kesehatan mereka karena lingkungan rumah yang tidak sehat bisa menimbulkan penyakit bagi para penghuni rumah. Selain rumah yang sesuai standar kesehatan, masyarakat juga perlu menerapkan pola hidup sehat yang akan mengurangi risiko terjadinya penyakit khususnya penyakit ISPA.

Konstruksi rumah dan lingkungan yang tidak memenuhi syarat kesehatan merupakan faktor risiko sumber penularan berbagai jenis penyakit. Penyakit infeksi 
saluran pernafasan akut (ISPA) dan tuberkolusis yang erat kaitannya dengan kondisi perumahan. Sanitasi rumah dan lingkungan erat kaitannya dengan angka kejadian penyakit menular, terutama ISPA. Beberapa hal yang dapat mempengaruhi kejadian penyakit ISPA adalah kondisi fisik rumah, kebersihan rumah, kepadatan penghuni dan pencemaran udara dalam rumah.Sehingga dapatdisimpulkan bahwa ada pengaruh antara status rumah yakni kepadatan hunian, ventilasi, jenis lantai, jenis dinding, jarak rumah dengan jalan raya, kebiasaan membersihkan rumah dari debu terhadap kejadian ISPA. Kejadian ISPA yang disebabkan oleh kondisi lingkungan rumah yang tidak sesuai dengan standar kesehatan dapat terjadi tentunya tidak lepas dari perilaku dan pengetahuan masyarakat dalam membangun rumah yang masih jauh dari standar rumah sehat. Kurangnya pengetahuan masyarakat menyebabkan masyarakat lebih memilih bangunan yang menggunakan bahan yang lebih murah tanpa memperhatikan efek samping dari bahan tersebut. Oleh karena itu perlu adanya sosialisasi dari pihak terkait sehingga masyarakat dapat memahami secara baik dan benar tentang membangun rumah yang sesuai dengan standar kesehatan karena rumah yang tidak sesuai standar kesehatan sangat berisiko menimbulkan penyakit ISPA pada penghuni rumah.

\section{KESIMPULAN DAN SARAN}

\section{Kesimpulan}

1. Berdasarkan hasil penelitian yang dilakukan diketahui bahwa sebagian besarrumah atau lingkungan fisik responden memenuhi syarat,akan tetapi memiliki ventilasi, jenis dinding serta jarak rumah dengan jalan raya yang tidak memenuhi syarat.

2. Berdasarkan penelitian yang dilakukan di Kecamatan Bontoala diketahui bahwa sebagian besar responden menderita ISPA

3. Hasil uji statistik menunjukkan pengaruh lingkungan fisik terhadap kejadian ISPA di Kecamatan Bontoala.

\section{Saran}

1. Bagi Dinas Kesehatan dan puskesmas sebaiknya memberikan sosialisasi/penyuluhan berkaitan dengan kejadian ISPA khusunya pengaruh lingkungan fisik terhadap kejadian ISPA dan memiliki data penderita ISPA yang lengkap.

2. Bagi masyarakat hendaknya memperhatikan keadaan lingkungan rumah dan kebiasan hidup sehat.

\section{DAFTAR PUSTAKA}

Aji Tulus. 2008. Faktor-faktor Lingkungan Fisik Rumah yang Berhubungan dengan Kejadian Pneumonia pada Anak Balita di Wilayah Kerja Puskesmas Kawunganten Kabupaten Cilacap. [Tesis]. Semarang: Universitas Diponegoro.

Cahya Indria. 2011. Kondisi Lingkungan Fisik Rumah terhadap Kejadian Infeksi 
Saluran Pernapsan Akut pada Balita di Wilayah Kerja Puskesmas Mergangsan Kota Yogyakarta. [Skripsi]. Depok:Universitas Indonesia.

Dinas Kesehatan Kota Makassar., 2005. Laporan ISPA Dinkes Kota Makassar.

Dinas Kesehatan Provisi Sulawesi Selatan. 2008. Profil Kesehatan Sulawesi Selatan. Makassar.

Dinas KesehatanProvisi Sulawesi Selatan. 2011. Laporan Program P2 ISPA Dinas Kesehatan Provinsi Sulawesi Selatan. Makassar.

Depkes R.I., 2001. Pedoman Pemberantasan Penyakit ISPA.Depkes RI. Jakarta.

Depkes R.I., 2004. Pedoman Pemberantasan Penyakit ISPA untukPenanggulangan Pneumonia pada Balita. Depkes RI. Jakarta.

Depkes R.I., 2006. Pedoman Pengendalian Penyakit ISPA untuk Penanggulangan Pneumonia pada Balita. Depkes RI. Jakarta.

Depkes R.I., 2008. LaporanhasilRisetKesehatanDasar.Riskesdas Indonesia Tahun 2007. Jakarta.

Depkes R.I. 2008. Surveilans Penyakit dan Masalah Kesehatan Berbasis Masyarakat. Direktorat Jenderal Pengendalian Penyakit dan Penyehatan Lingkungan. Jakarta.

Depkes R.I., 2011. Kualitas Udara dalam Rumah terhadap ISPA pada Balita. Direktorat Jenderal Pengendalian Penyakit dan Penyehatan Lingkungan. Jakarta.

Kementerian Kesehatan Republik Indonesia., 2011. Pedoman Pengendalian ISPA. Direktorat Jenderal Pengendalian Penyakit dan Penyehatan Lingkungan. Jakarta.

Kepmen No.1077/MENKES/PER/V/2011. Persyaratan Rumah Sehat. Jakarta.

Permenkes RI No.1077/MENKES/PER/V/2011., 2011. Pedoman Penyehatan Udara Dalam Rumah. Jakarta.

Safrizal SA. 2017. Hubungan Ventilasi, Lantai, Dinding, dan Atap dengan Kejadian ISPA pada Balita di Blang Muko. Prosiding Seminar Nasional I KAKESMADA, ISBN:978-979-3812-41-0.

Setyaningsih Wiwik, Dodiet AS, Ari Sarwanto. 2016. Studi Epidemiologi dengan Pendekatan Analisis Spasial terhadap Faktor-faktor Risiko Penyakit ISPA pada Anak di Kecamatan Sragen. Jurnal Keterapian Fisik, Volume 1, No. 1 : 01-74.

World Health Organization., 2012. Data and Statistics. 


\section{Lampiran 1. Odds Risk dan Relative Risks}

Kepadatan Hunian

\section{Risk Estimate}

\begin{tabular}{|l|r|r|r|}
\hline \multirow{2}{*}{} & \multicolumn{1}{|c|}{ Value } & \multicolumn{2}{|c|}{$\begin{array}{c}\text { 95\% Confidence } \\
\text { Interval }\end{array}$} \\
\cline { 3 - 4 } & & \multicolumn{1}{|c|}{ Lower } & \multicolumn{1}{c|}{ Upper } \\
\hline Odds Ratio for Kepadatan Hunian & 2.030 & .673 & 6.128 \\
(TMS / MS) & 1.288 & .876 & 1.895 \\
For cohort ISPA = Tidak ISPA & .635 & .305 & 1.322 \\
For cohort ISPA = Menderita ISPA & 59 & & \\
N of Valid Cases & & & \\
\hline
\end{tabular}

Kebiaasaan Membersihkan Rumah

Risk Estimate

\begin{tabular}{|l|r|r|r|}
\hline & \multicolumn{1}{|c|}{ Value } & \multicolumn{2}{|c|}{$95 \%$ Confidence Interval } \\
\cline { 3 - 4 } & & \multicolumn{1}{c|}{ Lower } & \multicolumn{1}{c|}{ Upper } \\
\hline Odds Ratio for Kebiasaan & 1.228 & .422 & 3.572 \\
Membersihkan (TMS / MS) & 1.079 & .729 & 1.597 \\
For cohort ISPA = Tidak ISPA & .879 & .447 & 1.729 \\
For cohort ISPA = Menderita ISPa & 59 & & \\
N of Valid Cases & & & \\
\hline
\end{tabular}

Ventilasi

Risk Estimate

\begin{tabular}{|l|r|r|r|}
\hline & \multicolumn{1}{|c|}{ Value } & \multicolumn{2}{|c|}{$95 \%$ Confidence Interval } \\
\cline { 3 - 4 } & & \multicolumn{1}{c|}{ Lower } & \multicolumn{1}{c|}{ Upper } \\
\hline Odds Ratio for Ventilasi (TMS / & .814 & .280 & 2.369 \\
MS) & .927 & .626 & 1.372 \\
For cohort ISPA = Tidak ISPA & 1.138 & .578 & 2.239 \\
For cohort ISPA = Menderita ISPA & 59 & & \\
N of Valid Cases & & \\
\hline
\end{tabular}

Jarak Rumah dengan Jalan Raya

Risk Estimate

\begin{tabular}{|l|r|r|r|}
\hline & \multirow{2}{*}{ Value } & \multicolumn{2}{|c|}{$95 \%$ Confidence Interval } \\
\cline { 3 - 4 } & & \multicolumn{1}{c|}{ Lower } & \multicolumn{1}{c|}{ Upper } \\
\hline Odds Ratio for Jarak Rumah dengan & 1.167 & .351 & 3.881 \\
Jalan raya (TMS / MS) & & & \\
For cohort ISPA = Tidak ISPA & 1.061 & .663 & 1.696 \\
For cohort ISPA = Menderita ISPA & .909 & .437 & 1.892 \\
N of Valid Cases & 59 & & \\
\hline
\end{tabular}


Lantai

Risk Estimate

\begin{tabular}{|l|r|r|r|}
\hline & \multicolumn{1}{|c|}{ Value } & \multicolumn{2}{|c|}{$95 \%$ Confidence Interval } \\
\cline { 3 - 4 } & & \multicolumn{1}{|c|}{ Lower } & \multicolumn{1}{c|}{ Upper } \\
\hline Odds Ratio for Lantai Rumah (TMS & .768 & .155 & 3.802 \\
/ MS) & .900 & .459 & 1.767 \\
For cohort ISPA = Tidak ISPA & 1.173 & .464 & 2.965 \\
For cohort ISPA = Menderita ISPA & 59 & & \\
N of Valid Cases & & & \\
\hline
\end{tabular}

Dinding

Risk Estimate

\begin{tabular}{|l|r|r|r|}
\hline & \multicolumn{1}{|c|}{ Value } & \multicolumn{2}{|c|}{$95 \%$ Confidence Interval } \\
\cline { 3 - 4 } & & \multicolumn{1}{|c|}{ Lower } & \multicolumn{1}{c|}{ Upper } \\
\hline Odds Ratio for Lantai Rumah (TMS & 5.294 & 1.499 & 18.695 \\
/ MS) & 1.716 & 1.167 & 2.521 \\
For cohort ISPA = Tidak ISPA & 0.324 & 0.125 & 0.839 \\
For cohort ISPA = Menderita ISPA & 59 & & \\
N of Valid Cases & & & \\
\hline
\end{tabular}




\section{Lampiran 2. Dokumentasi}
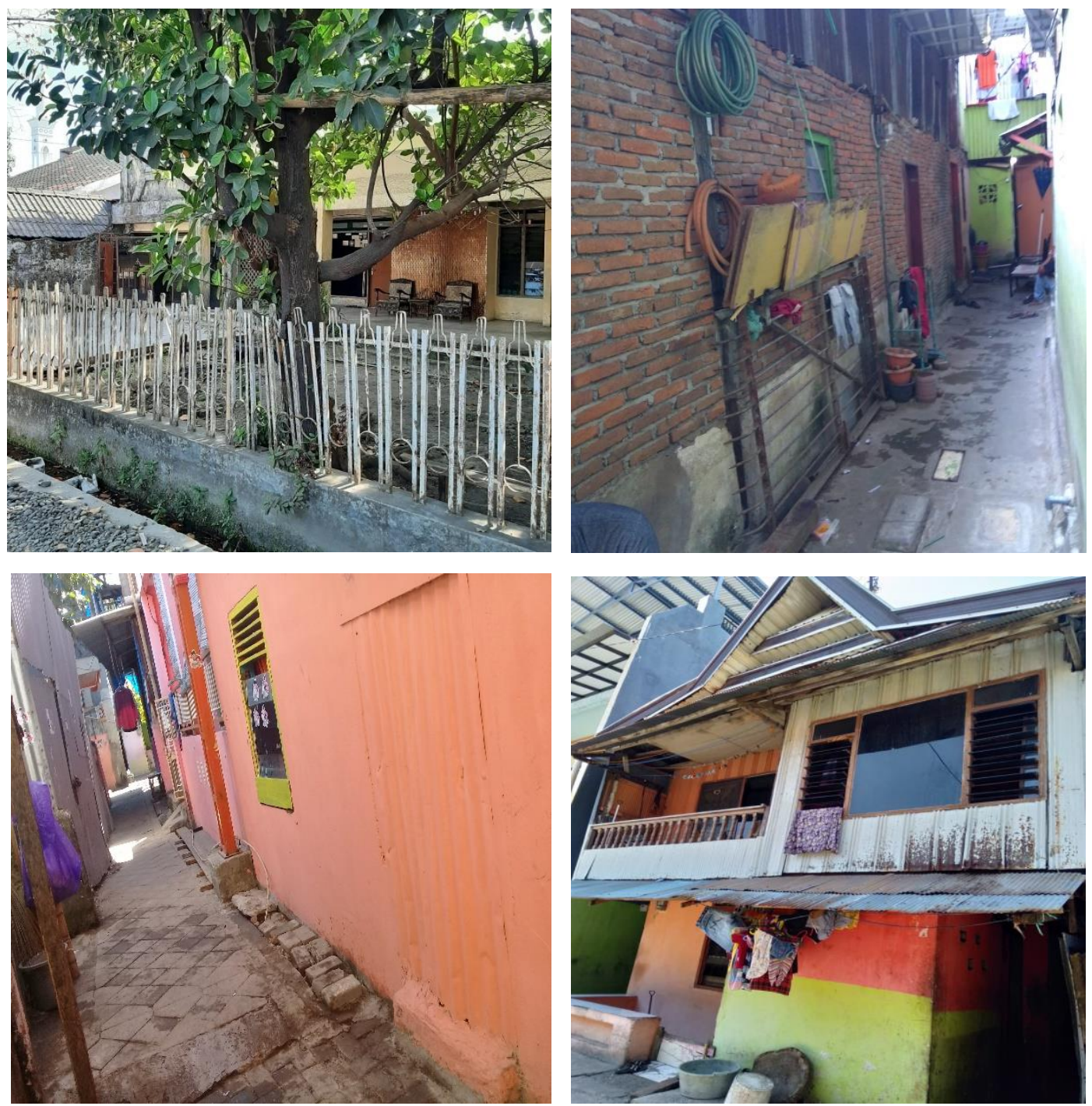

Gambar 1. Keadaan Lingkungan Fisik Rumah

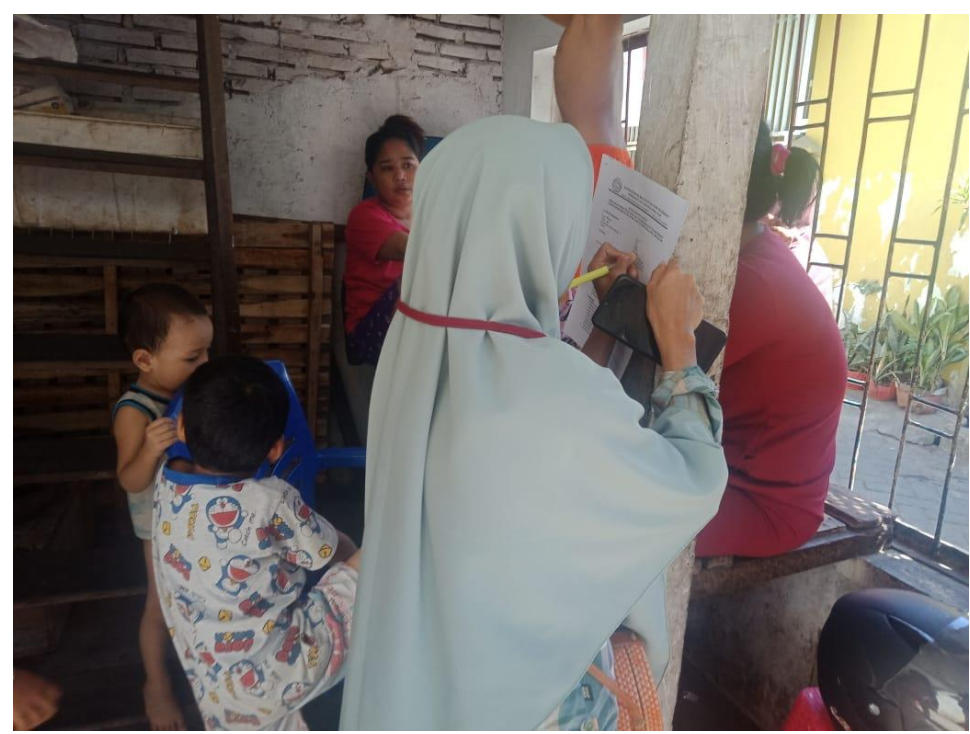



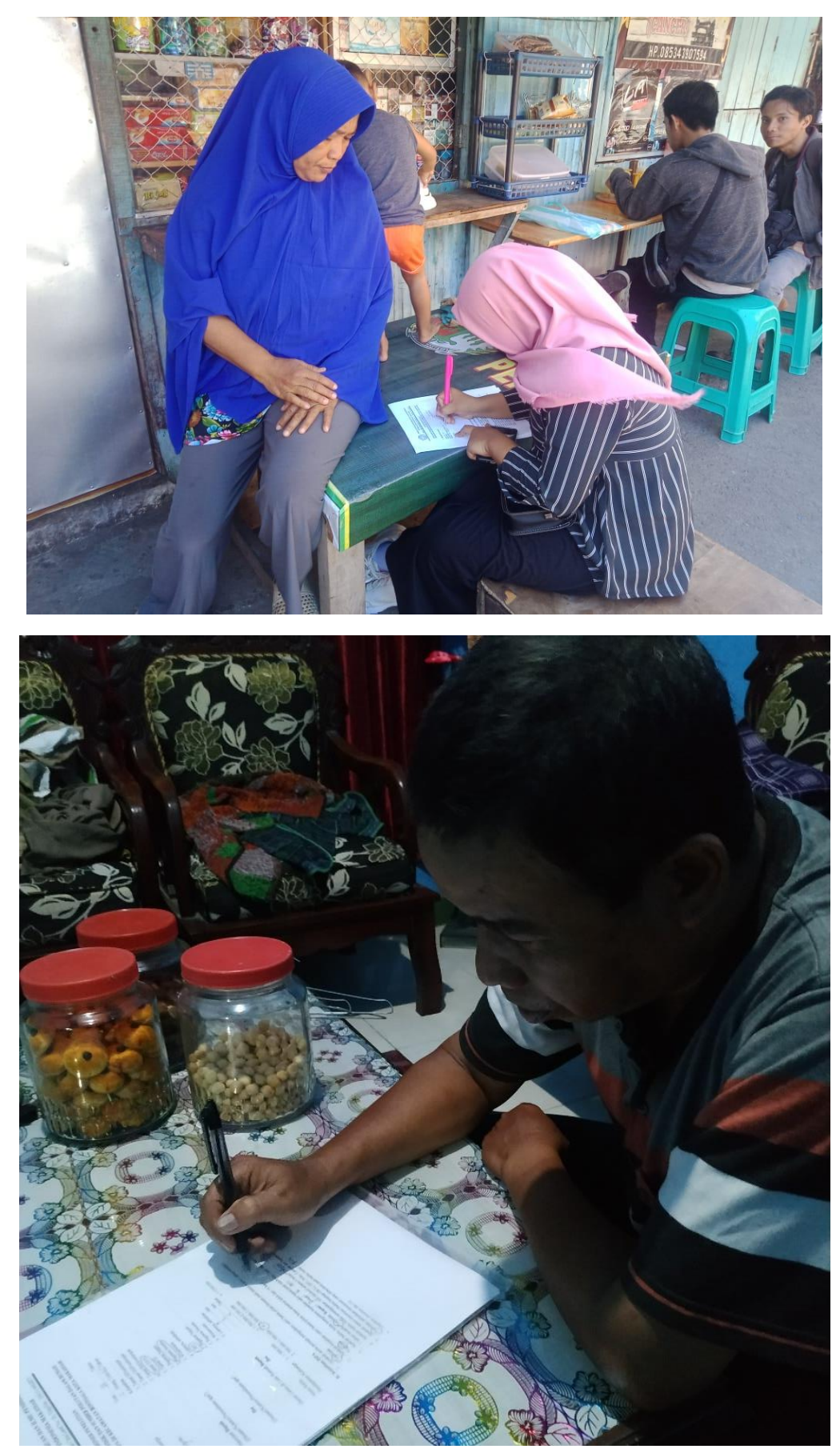

Gambar 2. Responden di Kecamatan Bontoala 